\title{
Determination of the Level of Heavy Metals in Cow's Milk Collected from Butajirra and Meskan Districts, South Central Ethiopia.
}

\section{Amha Teklu Asayehegn ( $\nabla$ teklueshtu@gmail.com )}

Aksum University https://orcid.org/0000-0003-3889-1059

Ariaya Hymete

Addis Ababa University

Seifu Hagos

Addis Ababa University

Ayenew Ashenef

Addis Ababa University

\section{Research Article}

Keywords: Heavy metals, Cow milk, ICP-OES, MP-AES, Butajirra, Meskan, Ethiopia

Posted Date: June 10th, 2021

DOI: https://doi.org/10.21203/rs.3.rs-590489/v1

License: (c) (i) This work is licensed under a Creative Commons Attribution 4.0 International License.

Read Full License 
Determination of the level of heavy metals in Cow's milk collected from Butajirra and Meskan districts, south central Ethiopia.

Amha Teklu ${ }^{1,2^{*}}$, Ariaya Hymete ${ }^{1}$, Seifu Hagos ${ }^{3}$, AyenewAshenef ${ }^{1}$

1. Department of Pharmaceutical Chemistry and Pharmacognosy, School of Pharmacy, College of Health Sciences, Addis Ababa University, P.O. Box. 1176, Addis Ababa, Ethiopia

2. Department of Pharmacy, Aksum University, P.O. Box. 1010, Aksum, Ethiopia

3. Department of Nutrition and Dietetics, School of public Health, College of Health Sciences, Addis Ababa University, P.O. Box. 1176, Addis Ababa, Ethiopia

*Correspondence Email: teklueshtu@gmail.com

\begin{abstract}
Background: Milk is a complete food useful to promote growth and development of the infant mammals as it contains vital nutrients including proteins, essential fats, vitamins, and minerals, in a balanced proportion. Milk can also contain chemical hazards and contaminants, such as heavy metals which can be a risk for health. This study was aimed at determining the level of the heavy metals in cow's milk collected from Butajirra and Meskan districts, south Ethiopia. Cows' milk was collected from 193 healthy and lactating cows. Samples were digested by optimized
\end{abstract}


microwave digestion method using $\mathrm{HNO}_{3}$ and $\mathrm{H}_{2} \mathrm{O}_{2}$. Analysis was done using ICP-OES for $\mathrm{Cd}$, $\mathrm{Cr}, \mathrm{Cu}, \mathrm{Fe}, \mathrm{Mn}, \mathrm{Ni}, \mathrm{Pb}$, and $\mathrm{Zn}$. MP-AES was used for $\mathrm{Ca}, \mathrm{Mg}, \mathrm{K}$ and $\mathrm{Na}$.

Results: Ni was not detected in all the milk samples. The concentrations of metals in the studied milk samples were, $\mathrm{Cd}(0.0-0.03), \mathrm{Cr}(0.0-0.4), \mathrm{Cu}(0.03-1.1), \mathrm{Fe}(0.0-1.9), \mathrm{Mn}(0.0-0.7)$, $\mathrm{Pb}(0.0-12.3), \mathrm{Zn}(0.0-8.2), \mathrm{Ca}(380.1-532.4), \mathrm{Mg}(159.6-397.9), \mathrm{K}(1114.2-1685.8)$ and Na (495.9-1298.3) ppm. These values were compared with guide lines of different international organizations for food and other available literatures. $\mathrm{Cd}, \mathrm{Cr}, \mathrm{Cu}, \mathrm{Mn}, \mathrm{Pb}, \mathrm{Zn}$ and $\mathrm{Mg}$ were found over the permissible limits.

Conclusion: Special attention should be given to the level of heavy metals in cows' milk, since they are difficult to remove from the body and are dangerous to health once they accumulate to a level greater than their limit.

Keywords: Heavy metals, Cow milk, ICP-OES, MP-AES, Butajirra, Meskan, Ethiopia. 


\section{Background}

Milk is a complex mixture of bioactive substances helpful to promote growth and development of infants in mammals (Qin et al., 2009). Milk is widely consumed by children and adults as it is an important food item and beneficial for health and growth. Milk contains fat, proteins, carbohydrates, vitamins, and minerals (Santos et al., 2015). According to Tetra Pak Dairy Index, global milk consumption has grown from 212 billion liters in 2013 to 223 billion liters in 2016. The significant increase in demand for dairy products is being fueled primarily by emerging markets China, India, South and South East Asia, Africa, as well as the Greater Middle East). This had been driven by economic growth and urbanization around the globe ( Steyn, 2015).

The potential for future expansion of dairy consumption remains significant, as income levels continue to grow in developing countries, especially in countries where levels of per capita consumption are still relatively low (Gerosa and Skoet, 2012). For example, from 1990 to 2000 total milk production in Ethiopia grew at an estimated rate of $3 \%$ compared to $1.8 \%$ during the period from 1975-1990 (Ahmed et al., 2000). The consumption level is significantly correlated with household income, family size, education level and location of the household (Melesse and Beyene, 2009).

Milk must be of satisfactory quality in order to protect the health of the community. It should be obtained from healthy animals. The collection and storage procedure should be under hygienic conditions that avoid contamination (Qin et al., 2009).

Heavy metals are a general collective term used for those elements with a specific density at least five times the specific gravity of water. Heavy metals include $\mathrm{Cd}, \mathrm{Cu}, \mathrm{Pb}, \mathrm{Zn}, \mathrm{Cr}$, and $\mathrm{Fe}$. Some 
of them $(\mathrm{Zn}$ and $\mathrm{Fe})$ are essential trace elements for living organisms when consumed at low concentration. However, they become toxic at high concentration. Most of these metal ions $(\mathrm{Cd}$, $\mathrm{Cu}, \mathrm{Zn}, \mathrm{Cr}$ and $\mathrm{Fe}$ ) are released from the industries in simple cationic forms (Volesky and MayPhillips, 1995). Now days, the contamination of milk with toxic elements is a global concern (Arianejad et al., 2015).This is because of the increasing industrial, vehicle and agricultural processes which can result in increased concentration of toxic heavy metals in the air, water, plants and soil (Yahaya et al., 2010).

Heavy metals such as $\mathrm{Cd}$ and $\mathrm{Pb}$ are common air pollutants and are emitted into the air as a result of various industrial activities. Although the atmospheric levels are low, they contribute to the deposition and build-up in soils. Various industrial environmental contamination of soil, waters, foods and plants with these metals cause their incorporation into the food chain and impose threat to human and animal health (Bilandžić et al., 2011).

The bioaccumulation nature of heavy metals in the environment makes them very dangerous for living organisms. Heavy metals cannot be degraded and are very toxic even at low concentration. When living organisms are exposed to these compounds from food chain such as milk, they are accumulated and stored at a rate faster than their metabolism and excretion (Tsoumbaris and Papadopoulou, 1994).

These heavy metals are taken in by plants and consequently accumulate in their tissues. The accumulation of toxic heavy metals leads to metabolic disorders and serious health problems such as weakness, heart failure, cancer, and kidney problem (Licata et al., 2004). 
The toxic effect of heavy metals depends on the total amount absorbed, route of exposure, duration of exposure and age of the person. For example, young children are more susceptible to the effects of $\mathrm{Pb}$ exposure because they absorb several times more of the percent ingested and yet to develop excretory system compared with adults (Tungegova et al., 2016).

There is evidence that milk and other dairy products might contain varying amounts of different toxic contaminants. Causes for the presence of heavy metals in cow's milk are due to exposure of the cows to contaminated feed sources like grass, drinking water, dust that settle on the grass, pharmaceutical medicines and their bioaccumulation process which potentially influence human health (Singh et al., 2010, Amponsah, 2014)

Therefore, information on the level of heavy metals in cow's milk is important in assessing risk to human health. Currently, many analytical methods are being developed and validated to perform accurate measurements of pollutants such as heavy metals in environmental matrices in order to assess compliance with national and international legislations. Those legislations limit the allowable concentration of pollutants in the atmosphere to ultra-trace levels. When analytical methods are performed, validation is often supported by primary standards and certified reference materials at low concentrations, developed for the purpose of accurate calibration, with a traceable uncertainty statement (Brown et al., 2005).

Among the modern analytical methods for accurate determination and quantification of metals in different samples, flame atomic absorption spectrometry(Alem et al., 2015), Graphite furnace atomic absorption spectroscopy (Arianejad et al., 2015), atomic emission/fluorescence spectrometry (Abdelkhalek et al., 2015), inductively coupled plasma mass spectrometry(Tanase et al., 2012), inductively coupled plasma optical emission spectrometry (Canbay and Doğantürk, 
2017), and microwave plasma atomic emission spectroscopy (Kamalaet al., 2014) are the most predominant techniques.

The heavy metal concentration values need to be compared with recommended dietary allowance (RDA) values. It is also advisable to compare with the corresponding values for milk in different countries as reported in literatures. In this study cow's milk was collected from Butajirra and Meskan districts South Central Ethiopia to determine its heavy metal levels by using inductively coupled plasma-optical emission spectrometry and microwave plasma atomic emission spectroscopy. 


\section{Materials and Methods \\ Description of the Study Area}

A cross sectional study was conducted from July to August 2017 with respect to sample collection to determine the level of heavy metals in cow's milk in Butajirra and Meskan districts. Butajirra is a town and separate district in south central Ethiopia located at the base of the Zebider massif in the Gurage zone of the Southern Nations Nationalities and People's Region (SNNPR). The town of Butajira is surrounded by Meskane and located about $130 \mathrm{~km}$ south of Addis Ababa, Ethiopia as shown in Figure 1 (Sinaga et al., 2015). According to Butajirra's livestock and fish development office there are about 14,000 milking cows and daily milk production is estimated to be greater than 3500 litters. The district consists of 30 peasant associations, 65 private herders and two agro-industries. The total population of the district is estimated to be 78,000. Four out of five "kebeles", (lower level of village administrative district in Ethiopia) (named kebeles 01, 02, 03 and 04) were purposively selected from Butajirra district.

According to the district's livestock and fish development office there are about 34,198 milking cows and the total population of the Meskan district is estimated to be 196,000. Three kebeles were selected from Meskan district based on their climatic condition to accommodate the three agro climatic conditions of Ethiopia. The selected sites were: Enseno town (lowland), Mekicho (middle land) and Huletenya Wolensho (highland) (Berhane and Byass, 2002).

The societies in Butajirra and Meskan districts are supported by farming in agro-pastoral settings. They grow cereals, false banana ('enset') and Catha eduslis Forsk (Khat) Berg et al., (2009),Nana (2016). In the study area there is a dietary practice serving individuals with milk 
during any time while having their meal. The daily milk consumption rate for Ethiopia was reported as $53 \mathrm{~g} /$ day (Belete et al., 2014). So, the study areas were chosen in expectation of high milk consumption.

\section{Sample collection}

The polyethylene sampling bottles were soaked in $\mathrm{HNO}_{3}$ and were rinsed with deionized water before collection of fresh cow's milk in order to avoid possible contamination.

For this study, a total of one hundred ninety-three healthy and lactating cows were randomly selected from Butajirra and Meskan districts; Eighty-five and one hundred eight cows respectively. The health of the selected lactating cows was ascertained by veterinarians practicing in the area. Samples were labeled into 17 different codes 8 of which were unmixed (taken from single cow) and the remaining 9 were mixed (prepared by taking about $6 \mathrm{ml}$ from 20 cows). The purpose of collecting mixed samples was to minimize cost for determination. Eight unmixed samples were prepared from randomly selected four cows at Butajirra and four cows at Meskan; $125 \mathrm{~mL}$ milk was taken from each cow, and put directly into eight sterile screw cupped bottles. Nine homogenized samples were also prepared from randomly selected eighty-one cows at Butajirra and one hundred four cows at Meskan; about $6 \mathrm{~mL}$ milk was taken from each cow directly into nine sterile screw cupped bottles. Twenty cows were included in the preparation of each homogenized sample. These samples were collected manually at any time of the day from both districts by the farmers and the quality of sample collection process was directly observed. The udder of each cow was washed with tap water and then rinsed thoroughly with distilled water before milking. The samples were kept in an ice box and were maintained under refrigeration for nine days until collection was completed. Finally, seventeen samples were 
transported to Addis Ababa and immediately kept in a deep freeze $\left(-20^{\circ} \mathrm{c}\right)$ until microwave digestion was carried out.

\section{Chemicals and reagents}

All the chemicals used were of analytical reagent grade. Nitric acid (68\%), hydrogen peroxide (32\%) (Sigma-Aldrich St. Louis, USA) and deionized water (having a resistivity of 18.2 million ohm-cm and conductivity of 0.055 micro Siemens) were used for cleaning sample holders and preparation of all solutions. Nitric acid (68\%) and hydrogen peroxide (32\%) were used for digesting milk samples throughout this work. The standard solutions (99.99 \%, ICP grade) of Ca (Lot BCB-L3192V), K (Lot GD16060759), Mg (Lot GD16060760), Na(Lot BCB-L2315V), Ni (Lot BCB-K4387V), Fe (Lot GD16060755), Cu (Lot BCB-M1539V), Cr(Lot BCB-K3741V), Mn (Lot BCB-R4235V), Pb (Lot GD16060764), Cd (Lot GD16060750) and Zn (Lot BCB$\mathrm{N} 8385 \mathrm{~V}$ ) corresponding to $1000 \mathrm{mg} / \mathrm{L}$ of each metal were prepared by sequential dilution of stock standards from Sigma-Aldrich (St. Louis, USA).

\section{Apparatus}

All glass wares were washed before use with deionized water to avoid contamination and then soaked in nitric acid, and rinsed with deionized water and finally the glasses were dried in oven. The glass wares were kept in desiccator, to avoid contamination. Milk samples were digested by using milestone start D microwave digester (START D, Milestone, Basel, Switzerland). ICPOES (Agilent 700 Series, California, USA) and MP-AES (Agilent 4200 Series, California, USA) for the determination of the heavy metals level in milk samples. 


\section{Sample digestion and preparation of analyte solution for ICP-OES and MP-AES}

The optimized microwave digestion procedure was selected depending upon the clarity of digests, minimal digestion time, and minimum reagent volume, absence of undigested milk samples, simplicity and low heating temperature. In this study $3 \mathrm{~mL}$ of cow's milk from each sample was treated with $9 \mathrm{~mL} 68 \%$ nitric acid and $2 \mathrm{~mL} \mathrm{32 \%} \mathrm{hydrogen} \mathrm{peroxide} \mathrm{and} \mathrm{were}$ transferred to dried digestion vessels. The digestion vessels were placed in a microwave digestion system at $180^{\circ} \mathrm{C}$ (30 min) and kept until brown fumes disappeared, indicating completion of oxidation of organic matter. After heating, the closed sample bottle was cooled to room temperature to avoid foaming and splashing and the digestion vessels were opened carefully in a fume hood. The cold clear solution was filtered in to $100 \mathrm{~mL}$ volumetric flask using Whatman filter paper $(0.45 \mu \mathrm{m}$ pore diameter membrane) to remove any suspended residues. $14 \mathrm{ml}, 1 \%$ nitric acid was added to the solution and diluted up to the mark with deionized water. Digestion of blanks was also performed in parallel with the milk samples keeping all the digestion parameters the same.

\section{Determination of metal contents of each digested sample by ICP-OES and MP-AES}

The measurements of levels of $\mathrm{Ni}, \mathrm{Zn}, \mathrm{Fe}, \mathrm{Cu}, \mathrm{Cr}, \mathrm{Mn}, \mathrm{Pb}$ and $\mathrm{Cd}$ were carried out with ICPOES. Before analysis of the sample, both MP-AES and ICP-OES were optimized using standard solutions of the metals to give maximum signal strength by adjusting the parameters such as wavelength, nebulizer flow, pump speed and lamp current for each element as shown in Table 1.

Calibration curves were drawn for $\mathrm{Ni}, \mathrm{Zn}, \mathrm{Fe}, \mathrm{Cu}, \mathrm{Cr}, \mathrm{Mn}, \mathrm{Pb}$ and $\mathrm{Cd}$ using linear regression analysis of the concentrations of the standard solutions versus emission values. Series of working standard solutions of metals were prepared by diluting the intermediate standard solution with 
deionized water. The same analytical procedure was employed for the determination of the elements in digested blank solutions and for the spiked samples. Three measurements were taken for each sample and the mean was plotted. Concentration of the metal ions present in the cow's milk was determined by reading their emission using ICP-OES and comparing it with the respective standard calibration curve. Correlation determination coefficient between concentrations and emission of the metals were done (Belete et al., 2014).

The correlation coefficients of calibration curves for $\mathrm{Zn}, \mathrm{Pb}, \mathrm{K}$, and $\mathrm{Ca}$ are given in Table 2. All the metallic elements exhibited linear relationships of the instrumental response and the solutions containing the metals with insignificant intercepts and coefficients of determination ( 0.994 or better). The correlation coefficient of more than 0.994 showed that there is strong linear relationship between concentrations and emission intensity. The solutions of $\mathrm{Ni}, \mathrm{Zn}, \mathrm{Fe}, \mathrm{Cu}, \mathrm{Cr}$, $\mathrm{Mn}, \mathrm{Pb}$, and $\mathrm{Cd}$ were aspirated into the plasma of the ICP-OES instrument and the emission value of the metals was recorded. The solutions of $\mathrm{Mg}, \mathrm{Na}, \mathrm{K}$ and $\mathrm{Ca}$ were aspirated into MPAES instrument and the emission value of the metals was recorded. Both the proposed analytical methods (ICP-OES and MP-AS) were observed to exhibit good linearity, confirming its reliability for determining trace levels of the heavy metals in cow's milk. Concentrations of each metal were determined from the emission versus concentration plotted calibration curves. For each sample triplicate determinations were performed and average results were reported.

\section{Method Validation}

\section{Precision and accuracy}


Analytical results must be evaluated to decide on the best values to report and to establish the probable limits of errors of these values (Kikuchi et al., 2002). In this study the precision of the results were evaluated by percentage relative standard deviation of the results of three samples (N=3) and triplicate readings for each sample giving a total of nine measurements for a given bulk sample. On the other hand, the accuracy and validity of the measurements were determined by analyzing spiked samples. In this study, milk samples were spiked by adding $1 \mathrm{~mL}$ from 1000 ppm metal standard solutions to three mL cow's milk.

The resulting mixtures were then digested, in triplicate for each sampled cow's milk, and analyzed in a similar manner as the milk sample. Then, the percentage recovery (\% R) was calculated for each of the selected element using the following equation:

$$
\text { Percentage Recovery }=\frac{\text { concentration in spiked sample }- \text { concentration in sample }}{\text { amount spiked }} \times 100
$$

The recovery percentages for $\mathrm{Ca}(98.3 \%), \mathrm{Cd}(99.4 \%), \mathrm{Cr}(97.4 \%), \mathrm{Cu}(96.6 \%), \mathrm{Fe}(98.1 \%), \mathrm{K}$ (98.8\%), Mg (97.1\%), Mn (95.6\%), Na (98.5\%), Ni (96.9\%), Pb (97.6\%) and $\mathrm{Zn}(97.3 \%)$ were found in this study.

In this study the variability in the method between the runs on the same day (intra-day variation), and the variability between runs on different days (inter day variation) was examined by using samples from a standard reference. In addition, reproducibility of the method was also checked by using samples from a standard reference. 


\section{Method Detection and Quantification Limits}

For determination of the detection limits of the method, blank sample was digested following the same procedure as the milk samples and each of the blank samples was analyzed for $\mathrm{Ni}, \mathrm{Zn}, \mathrm{Fe}$, $\mathrm{Cu}, \mathrm{Cr}, \mathrm{Mn}, \mathrm{Pb}$, and $\mathrm{Cd}$ by using ICP-OES and the same done for $\mathrm{K}, \mathrm{Na}, \mathrm{Mg}, \mathrm{Ca}$ by using $\mathrm{MP}-$ AES. The method detection limits and method quantification limits for MP- AES and ICP-OES are shown in Table 3. The standard deviation for each element was calculated from the blank measurements to determine method detection and quantification limits of the instrument.

\section{Statistical analyses}

Microsoft Office Excel 2016 was used to calculate the descriptive statistics (like mean, standard deviation) and draw calibration graphs. One-way analysis of variance (ANOVA) was performed to compare the differences among the samples using SPSS 20.0. Origin was used to draw graph for each metal in all samples (in $\mathrm{mg} / \mathrm{L}$ ). $\mathrm{P}<0.05$ was considered significant.

\section{Results and Discussion}

The average heavy metal concentrations of the seventeen sampled cows' milk collected from Butajirra and Meskan districts, south central Ethiopia are shown in Tables 4 and 5 respectively.

Twelve elements consisting toxic metals $(\mathrm{Mn}, \mathrm{Pb}$ and $\mathrm{Cd})$ and essential mineral elements $(\mathrm{Ca}, \mathrm{K}$, $\mathrm{Mg}, \mathrm{Na}, \mathrm{Ni}, \mathrm{Zn}, \mathrm{Fe}, \mathrm{Cu}$, and $\mathrm{Cr}$ ) were analyzed. The concentrations of these metals in milk samples were recorded in $\mathrm{mg} / \mathrm{L}(\mathrm{ppm})$ after calibration as presented in Tables 4 and 5 . Ni was not detected in all the milk samples. The concentrations of metals in the studied milk samples were, $\mathrm{Cd}(0.0-0.03), \mathrm{Cr}(0.0-0.4), \mathrm{Cu}(0.03-1.1), \mathrm{Fe}(0.0-1.9), \mathrm{Mn}(0.0-0.7), \mathrm{Pb}(0.0-$ 
12.3), Zn (0.0-8.2), Ca (380.1- 532.4), Mg (159.6- 397.9), K (1114.2-1685.8) and Na (495.91298.3) $\mathrm{ppm}$. Values obtained for $\mathrm{Cd}, \mathrm{Cr}, \mathrm{Pb}$ in this study were compared with the permissible limit set by Codex Alimentarius 2012. Those of $\mathrm{Fe}, \mathrm{Zn}, \mathrm{Ca}, \mathrm{K}, \mathrm{Mg}$ and $\mathrm{Na}$ were compared with the permissible limit set by Chinese foods standard 2010. The Mn value was compared with the permissible limit set by Japanese foods standard 2015 and $\mathrm{Cu}$ value with Egyptian standard 2001 as shown in Table 6. $\mathrm{Cd}, \mathrm{Cr}, \mathrm{Cu}, \mathrm{Mn}, \mathrm{Pb}, \mathrm{Zn}$ and $\mathrm{Mg}$ were found to be over the permissible limits in $12 \%, 6 \%, 53 \%, 65 \%, 82 \%, 6 \%$ and $100 \%$ of the samples respectively. The values over permissible limits of heavy metals in the study areas could be originated due to the commonly used underground water and animals' feed.

It is known that heavy metal contents in milk can vary widely due to many factors such as its secretion from the mammary gland, feeding, use of different water sources and industrial pollutions(Moreno et al., 1993,Caggianoa et al., 2005, Younus et al., 2016). As shown in Figure 2, Ni was not detected in all milk samples though $0.036 \mathrm{ppm}$ and $0.045-0.311 \mathrm{ppm}$ were reported by (Abou-Arab et al (2008) in Egypt and Arianejad et al (2015) in Iran respectively. This could be as a result of low exposure of cows to $\mathrm{Ni}$ in the study areas. Except cow milk samples (CM16 \& CM17), the results of ANOVA analysis showed that there are no significant differences among the $\mathrm{Cd}, \mathrm{Cr}, \mathrm{Cu}, \mathrm{Mn}, \mathrm{Pb}, \mathrm{Fe}$ and $\mathrm{Zn}$ level within samples and among the unmixed and homogenized samples collected from the two districts. The same is true for the $\mathrm{Ca}, \mathrm{Na}, \mathrm{K}$ and $\operatorname{Mg}(\mathrm{p}=0.05)$. Figure 2 (a) shows the metals which were found in a concentration greater than $245.5235 \mathrm{mg} / \mathrm{L}$ in all milk samples and Figure 2 (b) stands for metals which were found to be in concentrations less than $2 \mathrm{mg} / \mathrm{L}$. 
The concentration of $\mathrm{Cu}$ in this study ranged from $0.03-1.1 \mathrm{ppm}$. The average concentration in nine (53\%) milk samples was found to exceed the maximum permissible limit of $\mathrm{Cu}$ for cow's milk and dairy product taken as $0.4 \mathrm{mg} / \mathrm{L}$. The concentration of $\mathrm{Cu}$ obtained in the present study is close to $0.62-0.85,0.04-1.778$ and $0.17-1.79 \mathrm{ppm}$ the report made by Abdulkhaliq et al (2012) in Palestine,Muhib et al (2016) in Bangladesh andMohammed Imam et al (2017) in Nigeria respectively. Lower levels $0.087-0.122,0.181-0.229$ and $0.203-0.251$ ppm were reported by Belete et al (2014) in Ethiopia, Alem et al (2015) in Ethiopia, Maheswara and Murthy (2017) in Tanzania respectively. Cu is an essential trace element that plays a vital role in the physiology of animals for fetal growth and early post-natal development. Excess $\mathrm{Cu}$ in the body leads to Wilson's disease which is characterized by abdominal pain, fluid buildup in the legs or abdomen and problems with speech (Hassan and Masood, 2004 and Lawal et al., 2006).

In this study the concentration of $\mathrm{Pb}$ ranged from 0.00 for sample $\mathrm{CM}$, CM5 and $\mathrm{CM} 8$ to 12.30 ppm for sample CM16. Among the seventeen milk samples 14 (82\%) of them were found to contain $\mathrm{Pb}$ above the recommended dietary allowance for adult which is 0.02ppm. Except for samples CM16 \& CM17 the concentrations of Pb obtained in the present study are closer to $1.850-4.404$ and $1.87-2.34$ ppm compared to the report made by Mohammed Imam et al (2017) in Nigeria and Malhat et al (2012) in Egypt respectively, and higher than $0-0.93 \mathrm{ppm}$ and $0.0-0.39 \mathrm{ppm}$ the study made by Ahmad et al (2016) in Bangladeshand Abdulkhaliq et al (2012) in Palestine respectively. Like $\mathrm{Cu}$, high concentration of $\mathrm{Pb}$ in milk may result from consumption of contaminated feeding stuffs and the commonly used underground water in the redistricts. $\mathrm{Pb}$ has no beneficial biological function and is known to accumulate in the body. $\mathrm{Pb}$ exposure can cause adverse health effects, especially in young children and pregnant women. $\mathrm{Pb}$ is a neurotoxin that permanently interrupts normal brain development (Duruibe et al., 2007). 
Results presented in Table 4 and 5 show that, the average Cr concentration, in cow's milk analyzed ranged from $0.00-0.4 \mathrm{ppm}$ which is lower than $0.845-0.895$ and $0.468-0.828 \mathrm{ppm}$ reported by Belete et al (2014) and Akele et al (2017) in Ethiopia respectively and higher than $0.055-0.075$ and $0.0-0.11 \mathrm{ppm}$ reported by Alem et al (2015) in Ethiopia and Ahmad et al (2016) in Bangladesh respectively. Only sample CM13 one exceeded the permissible limit. Like other microelements $\mathrm{Cr}$ is essential to maintain the metabolic systems of human body but at higher level causing stomach upsets and ulcers, convulsions, kidney and liver damage, and even death (Qin et al., 2009).

All the average values of $\mathrm{Fe}$ in milk samples were found to be below permissible limit which ranged from $0.0-1.9 \mathrm{ppm}$. These values were lower than $10.95-16.38 \mathrm{ppm}$ and $3.21-12.91$ ppm reported by Malhat et al (2012) in Egypt and Abdulkhaliq et al (2012)in Palestine respectively. The mean concentrations of $\mathrm{Zn}$ ranged from $0.0-8.2 \mathrm{ppm}$. In this study the highest level of $\mathrm{Zn}$ was found in sample CM12 only. This result agrees with $5.003-6.218 \mathrm{ppm}$ reported byBelete et al(2014) in Ethiopia, higher result $4.770-10.75$ ppm was reported by Malhat et al(2012)in Egypt while lower results 1.96-3.640 ppm were reported by (Bano et al., 2015) in Pakistan.

Tables 4 and 5 shows that the $C d$ level ranged from $0.0-0.03 \mathrm{ppm}$. The average concentrations of Cd in this study is observed to be in agreement with $0.016-0.04 \mathrm{ppm}$ and $0.022-0.057 \mathrm{ppm}$ the report made by Abou-Arab et al (2008)in Egypt and Abdulkhaliq et al (2012)in Palestine respectively, but it is lower than the 0.200-0.288 ppm reported by (Malhat et al., 2012) in Egypt. The level of Mn in milk sample from all the sites ranged from $0.0-0.7 \mathrm{ppm}$ and $65 \%$ of the milk samples have above the limit. Lower levels $0.411-0.441 \mathrm{ppm}$ and $0.37-0.52$ were reported by 
Belete et al(2014) in Ethiopia andBano et al (2015) in Pakistan respectively. Exposure to high concentration of $\mathrm{Mn}$ is associated with mental and emotional disturbances, impaired male fertility, birth defects, and impaired bone development (Santamaria, 2008).

Magnesium was detected in all samples as shown in Tables 4 and 5. The levels of Mg in cow's milk in this study ranged from 159.6 - 397.9 ppm which is lower than the report made by Birghila et al (2008) 919.8 ppm in Romania. The mean concentration of $\mathrm{Mg}$ in this study is higher than the maximum standard indicated for food composition as shown in Table 6. Tables 4 and 5 indicated that the concentration of $\mathrm{K}$ in this study ranged from $1114.2-1685.8 \mathrm{ppm}$ and this is higher than the value reported by Qin et al (2009) in China, which was $1000 \mathrm{ppm}$ and agrees with 1440 - 1780 ppm reported by Zamberlin et al (2012) in Croatia and 1510-1660 ppm by Pereira (2014) in Portugal. The mean concentration of $\mathrm{K}$ in this study is lower than the maximum standard indicated for food composition as shown in Table 6.

The mean values of $\mathrm{Ca}$ in this study ranged from $380.1-532.4 \mathrm{ppm}$ that was found to be below the limit set by Chinese food Guidelines (820-1130 ppm) and which is also much lower than the concentration reported by Qin et al (2009) in China 1000 ppm and agree with $195-1528$ ppm ,the result reported by Bano et al (2015) in Pakistan. The level of $\mathrm{Na}$ in samples from all the sites ranged from 495.9 - $1298.3 \mathrm{ppm}$ and this is higher than 361-574 ppm value reported byQin et al (2009) in China and 400 - 580 ppm by Zamberlin et al (2012)in Croatia. The mean concentration of $\mathrm{Na}$ in this study is lower than the maximum standard indicated for food composition as shown in Table 6. The high level of heavy metals in these districts could be from the contaminated feeding hay, agricultural inputs, and agricultural left over such as "geleba" 
(Dried hay of maize plantations after harvest), "Chid" (Teff (Ergratois teff) straw after harvest) and the commonly used underground water.

Assuming a value of $53 \mathrm{~g} /$ day for milk consumption in Ethiopia per Belete et al (2014) study, the daily intake of these metals are determined and are presented in Table 7. The estimated daily intake for each metal was calculated to assess the health risks associated with trace metals due to milk consumption. The last column shows the RDA values as set by institute of medicine 2011, FAO and WHO. The density of whole, full-fat milk is very close to the density of water, which is $1.0002 \mathrm{~g} / \mathrm{mL}$. Therefore, it is possible to assume that $53 \mathrm{~mL}$ is equal to $53 \mathrm{~g}$ of milk. $E D I\left(\frac{m g}{\text { day }}\right)=M c \times 53$

Where; $\mathrm{Mc}=$ metal concentrations in milk $(\mathrm{mg} / \mathrm{L}), 53 \mathrm{~g} / \mathrm{day}=$ daily milk consumption rate for Ethiopia (Belete et al., 2014).

The daily intake of the metals depends on both the concentration and the amount of food consumed (Farid, 2004). Since the EDI values of all the analyzed metals are below the RDA values, milk consumption at this level is safe in the study area even for children. This could be due to the less daily milk consumption rate in Ethiopia compared with $113 \mathrm{~g}$ /day in Mumbai reported byTripathi et al (1997), 124g/day in Spain reported by Schuhmacher et al (1993) and $224 \mathrm{~g} /$ day in USA reported by (Lopez et al., 1995).

\section{Conclusion}

In this study, seventeen samples of cow's milk, collected from Butajirra and Meskan districts, south central Ethiopia, were analyzed for their heavy metal levels using ICP-OES for $\mathrm{Cd}, \mathrm{Cr}, \mathrm{Cu}$, $\mathrm{Fe}, \mathrm{Mn}, \mathrm{Pb}, \mathrm{Ni}$, and $\mathrm{Zn}$, and MP-AES for $\mathrm{Ca}, \mathrm{K}, \mathrm{Mg}$ and $\mathrm{Na}$. The concentrations of $\mathrm{Cd}, \mathrm{Cr}, \mathrm{Cu}$, 
$\mathrm{Fe}, \mathrm{Mn}, \mathrm{Pb}, \mathrm{Zn}, \mathrm{Ca}, \mathrm{Mg}, \mathrm{K}$ and $\mathrm{Na}$ in the studied milk samples were found to bein the ranges of: $0.0-0.03,0.0-0.4,0.03-1.1,0.0-1.9,0.0-0.7,0.0-12.3,0.0-8.2,380.1-532.4,159.6-$ 397.9, 1114.2- 1685.8 and $495.9-1298.3$ ppm respectively. Ni was not detected in all milk samples. The average concentrations of heavy metals observed were comparable with some of the reported values in literatures and complies with guidelines of different international organizations for food. However, this study gives a clear picture of high concentrations of toxic metals $(\mathrm{Pb}, \mathrm{Cd}, \mathrm{Mn})$ in cow's milk consumed and supplied to the market by the inhabitants of the two districts. This high level could be due to cows' exposure to contaminated feed, underground water, grazing grass and plants in these areas.

\section{Ethical consideration}

Ethical clearance was obtained from the School of Pharmacy Ethical Review Board on July 24/2017 (Ref. No. ERB/SOP/37/09/2017) and from Addis Ababa University College of Health Sciences Institutional Review Board on March 08/2018 (Protocol No. 099/17/SPH). The purpose of the study was explained to farmers who took part in the study at Butajirra and Meskan districts. Sample collections were performed after verbal consent.

Declarations

\section{Availability of data and materials:}

All data generated in the study are included in the manuscript.

\section{Competing interests}

The authors did not have any conflict of interest to declare with respect to this work. 


\section{Funding}

Addis Ababa University thematic project funded this work. However, the funding had no role in the design, experimental work, interpretation and publication of this study.

\section{Authors' contributions}

AT and AA contributed to study design, sampling, instrumental analysis and writing; $\mathrm{AH}$ and AS contributed to study design, manuscript preparing, data analysis, paper review. All authors read and approved the final manuscript

\section{Acknowledgements:}

The authors are grateful to Addis Ababa University for funding. AT acknowledges Aksum University for the study leave granted to him while pursuing his MSc studies in Pharmaceutical Analysis and quality assurance at Addis Ababa University.

Author's details:

1. Department of Pharmaceutical Chemistry and Pharmacognosy, School of Pharmacy, College of Health Sciences, Addis Ababa University, P.O. Box. 1176, Addis Ababa, Ethiopia.

2. Department of Pharmacy, Aksum University, P.O. Box. 1010, Aksum, Ethiopia

3. Department of Nutrition and Dietetics, School of public Health, College of Health Sciences, Addis Ababa University, P.O. Box. 1176, Addis Ababa, Ethiopia 


\section{References}

Abdelkhalek A, Elsherbini M \& Gunbaej E(2015). Assessment of heavy metals residues in milk powder and infant milk formula sold in Mansoura City, Egypt. Alexandria Journal of Veterinary Sciences, 47: 71-77.

Abdulkhaliq A, Swaileh K, Hussein M \& Matani M (2012). Levels of metals (Cd, Pb, Cu and Fe) in cow's milk, dairy products and hen's eggs from the West Bank, Palestine. International Food Research Journal,19: 1089-1094.

Abou-Arab A, Abou-Donia M \& Enb A (2008). Chemical composition, metals content and pesticide residues in raw, pasteurized and UHT milk and their dietary intake. Journal of the Egyptian Society of Parasitology,39: 111-121.

Ahmad M, Roy S, Sarwar N, Morshed S, AlamM, Matin A \& Kobra T (2016). Contamination of raw milk, market pasteurized milk and powdered milk by toxic heavy metals in Bangladesh. Scientific Research Journal,4: 19-24.

Ahmed M, Jabbar M \& Ehui S(2000). Household-level economic and nutritional impacts of market-oriented dairy production in the Ethiopian highlands. Food and Nutrition Bulletin,21: 460-465.

Ahuja A, Threja H, Singh P \& Sahota H (2015). Analytical techniques for trace element analysis: an overview. International Journal of Engineering Research and General Science,3: 887895.

Akele M, Abebe D, Alemu A, Assefa G\&Madhusudhan A (2017). Analysis of trace metal concentrations in raw cow's milk from three dairy farms in North Gondar, Ethiopia: chemometric approach. Environment Monit Assess,3: 499-511. 
Alem G, Tesfahun K \& Kassa B (2015). Quantitative determination of the level of selected heavy metals in the cows' milk from the Dairy Farm of the Haramaya University, Eastern Ethiopia. International Journal of Chemical and Natural Science,3: 240-248.

Amponsah D (2014). Determination of levels of heavy metals (arsenic, lead, cadmium and mercury) in tin milk produced in Ghana. International Journal of Advancements in Research \& Technology,3: 129-133.

Arianejad M, Alizadeh M, Bahrami A \& Arefhoseini R(2015). Levels of some heavy metals in raw cow's milk from selected milk production sites in Iran: Is There any Health Concern? Health promotion perspectives,5: 176-182.

Ayar A, Sert D \& Akın N(2009). The trace metal levels in milk and dairy products consumed in middle Anatolia-Turkey. Environmental monitoring and assessment,152: 1-12.

Bader R. (2011). Sample preparation for flame atomic absorption spectroscopy: an overview. Rasayan Journal of Chemistry,4: 49-55.

Bano H, Mahmood A \& Ain U(2015). Comparative study of zinc, manganese and calcium in commercially available milk samples. International Journal of Advanced Research,3: 982993.

Belete T, Hussen A \& Rao M (2014). Determination of concentrations of selected heavy metals in cow's milk: Borena Zone, Ethiopia. Journal of Health Science,4: 105-112.

Berg S, Firdessa R, Habtamu M, Gadisa E, Mengistu A, Yamuah L, Ameni G, Vordermeier M, Robertson D \& Smith H (2009). The burden of mycobacterial disease in Ethiopian cattle: implications for public health. Public Library of Science,4: 1-8.

Berhane Y \& Byass P (2002). Butajira DSS Ethiopia. Population and health in developing countries, 1: 1-10. 
Bilandžić N, Đokić M, Sedak M, Solomun B, Varenina I, Knežević Z \& Benić M (2011). Trace element levels in raw milk from northern and southern regions of Croatia. Food Chemistry, 127: 63-66.

Birghila S, Dobrinas S, Stanciu G \& Soceanu A (2008). Determination of major and minor elements in milk through ICP-AES. Environmental Engineering \& Management Journal,7: 805-808.

BrownJ \& Milton J (2005). Analytical techniques for trace element analysis: an overview. Trends in Analytical Chemistry,24: 266-274.

Caggianoa M, Sabiaa M, D’emiliob A, Ragostad M \& Painoe S(2005). Metal levels in fodder, milk, dairy products, and tissues sampled in ovine farms of Southern Italy. Environmental Research,99: 48-57.

CanbayS \& Doğantürk M (2017). Metals determination by microwave digestion ICP-OES of some dietary supplements and diet products in Turkey. Eurasian Journal of Analytical Chemistry, 12: 45-53.

Cynthia I \& Mansour S (2009). Food and agricultural import regulations and standards narrative. Global Agricultural Information Network, 29: 253-272.

Donati L, Amais S, Schiavo D \& Nobrega A (2013). Determination of $\mathrm{Cr}, \mathrm{Ni}, \mathrm{Pb}$ and $\mathrm{V}$ in gasoline and ethanol fuel by microwave plasma optical emission spectrometry. Journal of Analytical Atomic Spectrometry, 28: 755-759.

DuruibeS, Ogwuegbu R \& Egwurugwu M (2007). Heavy metals pollution and human toxic effects International Journal of Physical Science, 2: 112-118. 
Eka N, Retno S \& Rohman A (2012). Validation and quantitative analysis of cadmium and lead in snake fruit by flame atomic absorption spectrophotometry. International Food Research Journal,19: 937-940.

Ershow A \& Wong K (1990). Chinese food composition tables an annotated translation of the 1981 edition published by the institute of nutrition and food hygiene, Chinese academy of preventive medicine, Beijing. Journal of Food Composition and Analysis,3: 191-434.

Farid M (2004). Determination of trace elements in cow's milk in Saudi Arabia. Engineering Sciences, 15: 131-140.

Gerosa S \& Skoet J (2012). Milk availability: trends in production and demand and mediumterm outlook. Food and Agriculture Organization of the United Nations,12: 1-38.

Hassan A \& Masood F (2004). Wilson's disease: a review. Journal Pakistan Medical Association,54: 479-484.

Helaluddin A, Khalid S, Alaama M \& Abbas A (2016). Main analytical techniques used for elemental analysis in various matrices. Tropical Journal of Pharmaceutical Research,15: 427-434.

Hou X, Amais S, Jones B, \& Donati G (2000). Inductively coupled plasma optical emission spectrometry. Encyclopedia of Analytical Chemistry,7: 11-19.

HoukS, FasselA, FleschD, SvecJ, GrayL \& TaylorE(1980). Inductively coupled argon plasma as an ion source for mass spectrometric determination of trace elements. Analytical Chemistry,52: 2283-2289.

Institute of Medicine (2011): Recommended dietary allowances: Calcium, chromium, copper, fluoride, iodine, iron, magnesium, manganese, molybdenum, phosphorus, selenium, zinc, 
potassium, sodium, chloride. Washington DC: National Academy Press. http://iom.edu/ (Accessed: 12.08.2018.).

Kamala C, Balaram V, Dharmendra V, Satyanarayanan M, Subramanyam K \& Krishnaiah A (2014). Application of microwave plasma atomic Emission Spectrometry for environmental monitoring of industrially contaminated sites in Hyderabad City. Environmental Monitoring and Assessment, 186: 7097-7113.

Kikuchi T, Nomiyama N, Kumagai T, Uemura L \& Omae K (2002). Cadmium concentration in current Japanese food and beverages. Journal of Occupational Health,44: 240-247.

Lajunen L \& Perämäki P (2004). Spectrochemical analysis by atomic absorption and emission. Royal Society of Chemistry, 2: 6-8.

Lamble J \& Hill S(1998). Microwave digestion procedures for environmental matrices. Critical Review. Analyst,123: 103-133.

Lawal O \&Mohammed D (2006). Assessment of levels of copper, cadmium and lead in secretion of mammary gland of cows grazed on open fields. The Scientific World Journal,1: $7-10$.

Lewis M, Worobey J, Ramsay S \& Mccormack K (1992). Prenatal exposure to heavy metals: effect on childhood cognitive skills and health status. Pediatrics,89: 1010-1015.

Licata P, Trombetta D, Cristani M, Giofre F, Martino D, Calo M \& Naccari F (2004). Levels of "toxic" and "essential" metals in samples of bovine milk from various dairy farms in Calabria, Italy. Environment International,30: 1-6.

Llobet M, Martí-Cid R, Castell V \& Domingo L (2008). Significant decreasing trend in human dietary exposure to PCDD/PCDFs and PCBs in Catalonia, Spain. Toxicology Letters, 178: 117-126. 
Lopez A, Collins W \& Williams H (1995). Essential elements, cadmium, and lead in raw and pasteurized cow and goat milk. Journal of Dairy Science, 68: 1878-1886.

Maheswara R \& Murthy A (2017). Determination of Concentrations of Selected Heavy metals in Cow's Milk: Dodoma Urban District, Tanzaniaa. International Journal of Engineering Research and Application, 7: 76-84.

Malhat F, Hagag M, Saber A \& Fayz E (2012). Contamination of cows milk by heavy metal in Egypt. Bulletin of Environmental Contamination and Toxicology,88: 611-613.

Melesse K \& Beyene F (2009). Consumption pattern of milk and milk products in Ada'aworeda, East Shoa Zone, central Ethiopia. Livestock Research for Rural Development,21: 1-13.

MeshrefM, Moselhy A \& HassanY (2014). Heavy metals and trace elements levels in milk and milk products. Journal of Food Measurement and Characterization, 8: 381-388.

Mohammed I, Zahra M \& Zakari A(2017). Determination of some heavy metals in milk of cow grazing at selected areas, of Kaduna Metropolis.International Journals of Advanced Research in Computer Science and Software Engineering, 7: 341-346.

Moreno R, Zurera G\& Amaro M(1993). Micronutrients in natural cow, ewe and goat milk. International Journal of Food Sciences and Nutrition,44: 137-46.

Muhib I, Chowdhury Z, EashaJ, RahmanM, Shammi M, Fardous Z, Bari L, Uddin K, Kurasaki M \& AlamK (2016). Investigation of heavy metal contents in cow milk samples from area of Dhaka, Bangladesh. International Journal of Food Contamination, 3: 1-10.

Nana T (2016). Prevalence of ovine gastrointestinal nematodes in Meskan district, Gurage zone, Southern Ethioipa. International Journal Multidisciplinary Advanced Research Trends,3: 22-30.

Nardi P, Evangelista S, Sainta D \& Souza S (2009). The use of inductively coupled plasma mass spectrometry (ICP-MS) for the determination of toxic and essential elements in different type of food samples.Food Chemistry,112: 727-732. 
OLIVEIRA D. (2003). Sample preparation for atomic spectroscopy: evolution and future trends. Journal of the Brazilian Chemical Society,14: 174-182.

Pereira C (2014). Milk nutritional composition and its role in human health. Nutrition,30: 619-627.

Qin, Wang, W, Tong X \& Tong W (2009). The minerals and heavy metals in cow's milk from China and Japan. Journal of Health Science, 55: 300-305.

Salah F, Esmat I. \& Mohamed A (2013). Heavy metals residues and trace elements in milk powder marketed in Dakahlia Governorate. International Food Research Journal,20: 1807-12.

Santamaria (2008). Manganese exposure, essentiality and toxicity. Indian Journal of Medical Research,128: 484-500.

Santos C, Oliveira A, Martins D, Oliveira J, Pedro F \& Villa R (2015). Determination of the concentrations of essential and toxic metals in UHT milk produced in Mato Grosso State, Brazil. International Food Research Journal,22: 981-986.

Schuhmacher M, Domingo J, Llobet J \& Corbella J (1993). Dietary intake of copper, chromium and zinc in Tarragona Province, Spain. Science of the Total Environment,132: 3-10

Sinaga M, Mohammed A, Teklu N, Stelljes K \& Belachew T (2015). Effectiveness of the population health and environment approach in improving family planning outcomes in the Gurage, Zone South Ethiopia. Biomedical Center Public Health,15: 1123-1135.

Singh A, Sharma K, Agrawal M \& Marshall M (2010). Health risk assessment of heavy metals via dietary intake of foodstuffs from the wastewater irrigated site of a dry tropical area of India. Food and Chemical Toxicology,48: 611-619.

Smith E \& Arsenault A. (1996). Microwave-assisted sample preparation in analytical chemistry. Talanta,43: 1207-68.

Sneddon J (2002). Advances in atomic spectroscopy. Elsevier Science, 21: 244-257. 
Sperling M (2000). Flame and graphite furnace atomic absorption spectrometry in environmental analysis. Encyclopedia of Analytical Chemistry,63: 221-229.

Sroor A, El-Dine W, El-Shershaby A \& Abdel-Haleem A (2003). Major and trace elemental analysis in milk powder by inductively coupled plasma-optical emission spectrometry (ICPOES) and instrumental neutron activation analysis (INAA). Journal of Environmental Sciences, 15: 570-576.

Steyn N (2015). Dare to explore: processing. The Dairy Mail,22: 106-110.

Suleiman S, Hu B, Pu X, Huang C \& Jiang Z (2007). Nanometer-sized zirconium dioxide microcolumn separation/preconcentration of trace metals and their determination by ICPOES in environmental and biological samples. Microchimica Acta,159: 379-385.

Tanase G, Udristioiu F, Bunaciu A \& Aboul-Enein Y (2012). Trace Elements Analysis in Paper Using Inductively Coupled Plasma - Mass Spectrometry. Gazi University Journal of Science, 25: 843-851.

Temiz H \& Soylu, A (2012). Heavy metal concentrations in raw milk collected from different regions of Samsun, Turkey. International Journal of Dairy Technology,65: 516-522.

Tripathi R, Raghunath R \& Krishnamoorthy T (1997). Dietary intake of heavy metals in Bombay city, India. Science of the Total Environment, 208: 149-159.

Tritscher A, Miyagishima K, Nishida C \& Branca F (2013). Ensuring food safety and nutrition security to protect consumer health: 50 years of the Codex Alimentarius Commission. Bulletin of the World Health Organization,91: 468-468.

Tsoumbaris P \& Papadopoulou H (1994). Heavy metals in common foodstuff: quantitative analysis. Bulletin of Environmental Contamination and Toxicology,53: 61-66. 
Tungegova, Toman \& Tancin (2026). Heavy metals environmental contaminants and their occurrence in different types of milk. Slovak Journal of Animal Science,49: 122-131.

Vijay K, Alekhya G, Ajeesha S, Hima T \& Sireesha V (2012). Graphite furnace atomic absorption spectroscopy. Journal of Scientific Research in Pharmacy,1: 16-19.

Volesky B \& May-Phillips H(1995). Biosorption of heavy metals by Saccharomyces Cerevisiae. Applied Microbiology and Biotechnology,42: 797-806.

Vudagandla S, Siva N, Dharmendra V, Asif M, Balaram V, Zhengxu H \& Zhen Z (2017). Determination of boron, phosphorus, and molybdenum content in biosludge samples by Microwave Plasma Atomic Emission Spectrometry (MP-AES). Applied Sciences, 7: 264-268.

Vysetti B, Vummiti D, Roy P, Taylor C, Kamala C, Satyanarayanan M, Kar P, Subramanyam K, Raju K \& Abburi K (2014). Analysis of geochemical samples by microwave plasma-AES. Atomic Spectroscopy,35: 65-78.

Watanabe T \& Kawai R (2017). Advances in food composition tables in Japan-standard tables of food composition in Japan.Food chemistry,238: 16-21.

Yahaya M, Ezeh G, Musa Y \& Mohammad S (2010). Analysis of heavy metals concentration in road sides soil in Yauri, Nigeria. African Journal of Pure and Applied Chemistry,4: 022-030.

Younus M, Abbas T, Zafar M, RazaS, Khan A, Saleem A, Idrees M, Nisa Q, Akhtar R \& Saleem G (2016). Assessment of heavy metal contamination in raw milk for human consumption. South African Journal of Animal Science,46: 166-169.

Zamberlin Š, Antunac N, Havranek J \& Samaržija D (2012). Mineral elements in milk and dairy products. Mljekarstvo/Dairy,62: 111-125. 
Ziarati P, Shirkhan F, Mostafidi M \& Tamaskoni M (2018). An overview of the heavy metal contamination in milk and dairy products. Anti counterfeit Trade Agreement Scientific Pharmaceutical Sciences, 2: 8-21. 
Tables:

Table 1: MP-AES 4200 and ICP-OES 700 operational conditions for metal determination in milk

\begin{tabular}{|llllll|}
\hline Element & $\begin{array}{l}\text { Wavelength } \\
(\mathbf{n m})\end{array}$ & $\begin{array}{l}\text { Nebulizer } \\
\text { Flow } \\
(\mathrm{L} / \mathrm{min})\end{array}$ & $\begin{array}{l}\text { Replicates } \\
\text { Camp }\end{array}$ & $\begin{array}{l}\text { Pump } \\
\text { Speed(rpm) }\end{array}$ & $\begin{array}{l}\text { Read Time } \\
\text { (sec.) }\end{array}$ \\
\hline $\mathbf{K}$ & 422.673 & 0.4 & 3 & 10 & 2 \\
\hline $\mathbf{M g}$ & 286.491 & 0.8 & 3 & 10 & 2 \\
\hline $\mathbf{N a}$ & 588.995 & 0.4 & 3 & 10 & 2 \\
\hline $\mathbf{C d}$ & 214.439 & 15.0 & 3 & 10 & 3 \\
\hline $\mathbf{C r}$ & 205.560 & 15.0 & 3 & 15 & 3 \\
\hline $\mathbf{C u}$ & 324.754 & 15.0 & 3 & 15 & 3 \\
\hline $\mathbf{F e}$ & 238.204 & 15.0 & 3 & 15 & 3 \\
\hline $\mathbf{M n}$ & 257.610 & 15.0 & 3 & 15 & 3 \\
\hline $\mathbf{N i}$ & 230.299 & 15.0 & 3 & 15 & 3 \\
\hline $\mathbf{P b}$ & 220.305 & 15.0 & 3 & 15 & 3 \\
\hline
\end{tabular}

N.B: MP-AES $4200 \mathrm{Ca}, \mathrm{K}, \mathrm{Mg} \& \mathrm{Na}$, and ICP-OES 700 was used for $\mathrm{Cd}, \mathrm{Cr}, \mathrm{Cu}, \mathrm{Fe}, \mathrm{Mn}, \mathrm{Ni}$ and $\mathrm{Pb}$.

Table 2: Series of working standards and correlation coefficients of the calibration curves for the determination of metals in milk using MP-AES 4200 and ICP-OES 700

\begin{tabular}{|llll|} 
S.No. & Metals & Concentrations of standards $(\mathbf{p p m})$ & Correlation coefficient, $\mathbf{R}^{2}$ \\
\hline 1. & $\mathrm{Zn}$ & $1.0,3.0,5.0,7.0,10.0$ & 0.9996 \\
\hline 2. & $\mathrm{Pb}$ & $1.0,3.0,5.0,7.0,10.0$ & 0.9941 \\
\hline 3. & $\mathrm{K}$ & $0.5,1.0,5.0,20.0,30.0$ & 0.9999 \\
\hline 4. & $\mathrm{Ca}$ & $5.0,10.0,15.0,20.0$ & 0.9992 \\
\hline
\end{tabular}

Table 3: Limit of detection (LoD) and Limit of quantification (LoQ) in mg/L for MP-AES 4200 and ICP-OES 700.

\begin{tabular}{|llll|}
\hline Element & Wavelength $(\mathbf{n m})$ & LoD & LoQ \\
\hline $\mathbf{C a}$ & 422.7 & 0.002 & 0.0070 \\
\hline $\mathbf{K}$ & 766.5 & 0.067 & 0.2230 \\
\hline $\mathbf{M g}$ & 285.2 & 0.002 & 0.0070 \\
\hline $\mathbf{N a}$ & 588.9 & 0.117 & 0.3510 \\
\hline $\mathbf{C d}$ & 214.4 & 0.0010 & 0.0033 \\
\hline $\mathbf{C r}$ & 205.6 & 0.0010 & 0.0033 \\
\hline
\end{tabular}




\begin{tabular}{|llll|}
\hline $\mathbf{C u}$ & 324.8 & 0.0010 & 0.0033 \\
\hline $\mathbf{F e}$ & 238.2 & 0.0010 & 0.0033 \\
\hline $\mathbf{M n}$ & 257.6 & 0.0010 & 0.0033 \\
\hline $\mathbf{N i}$ & 230.3 & 0.0010 & 0.0033 \\
\hline $\mathbf{P b}$ & 220.3 & 0.0010 & 0.0033 \\
\hline $\mathbf{Z n}$ & 202.5 & 0.0010 & 0.0033 \\
\hline
\end{tabular}

Table 4: The mean concentration of heavy metals collected from Butajirra district

\begin{tabular}{|c|c|c|c|c|c|c|c|c|c|c|c|c|c|}
\hline \multicolumn{2}{|c|}{ Kebeles } & \multicolumn{12}{|c|}{ Concentrations of heavy metals (ppm) } \\
\hline \multirow[t]{4}{*}{01} & Sample code & $\mathrm{Cd}$ & $\mathrm{Cr}$ & $\mathrm{Cu}$ & $\mathrm{Fe}$ & $\mathrm{Mn}$ & $\mathrm{Ni}$ & $\mathrm{Pb}$ & $\mathrm{Zn}$ & $\mathrm{Ca}$ & K & $\mathrm{Mg}$ & $\mathrm{Na}$ \\
\hline & CM1(Un) & 0.03 & 0.1 & 0.03 & 0.05 & ND & ND & 0.7 & 0.4 & 532.4 & 1377.4 & 225.5 & 559.9 \\
\hline & CM5 (Un) & ND & ND & 0.5 & 0.3 & 0.1 & ND & ND & 0.4 & 380.1 & 1443.3 & 205.9 & 841.9 \\
\hline & CM6 (Mx) & ND & 0.02 & 0.7 & 1.0 & 0.4 & ND & 0.2 & 0.3 & 517.3 & 1145.9 & 188.5 & 788.6 \\
\hline \multirow[t]{2}{*}{02} & CM9 (Mx) & ND & 0.04 & 0.9 & 0.3 & 0.5 & ND & 0.1 & 0.3 & 427.4 & 1588.2 & 180.9 & 727.8 \\
\hline & CM16(Mx) & ND & ND & 0.6 & 0.7 & 0.6 & ND & 12.3 & 1.3 & 498.3 & 1556.3 & 232.0 & 791.2 \\
\hline \multirow[t]{2}{*}{03} & CM11(Mx) & ND & 0.1 & 1.1 & 1.9 & 0.7 & ND & 2.9 & 1.0 & 503.9 & 1672.8 & 207.7 & 796.9 \\
\hline & CM12(Un) & ND & ND & 0.1 & ND & 0.5 & ND & 0.5 & 8.2 & 514.3 & 1685.8 & 195.7 & 495.9 \\
\hline \multirow[t]{3}{*}{05} & CM3 (Mx) & 0.03 & 0.1 & 0.2 & 0.7 & 0.03 & ND & ND & 0.9 & 435.6 & 1438.7 & 189.6 & 697.7 \\
\hline & CM17(Un) & ND & ND & 0.5 & 0.5 & 0.6 & ND & 12.1 & 1.3 & 526.5 & 1585.7 & 210.5 & 740.6 \\
\hline & Blank & ND & ND & ND & ND & ND & ND & ND & ND & ND & ND & ND & ND \\
\hline
\end{tabular}

Table 5: The mean concentration of heavy metals collected from Meskan district

\begin{tabular}{|c|c|c|c|c|c|c|c|c|c|c|c|c|c|}
\hline \multicolumn{2}{|l|}{ Sites } & \multicolumn{12}{|c|}{ Concentrations of heavy metals (ppm) } \\
\hline \multirow{4}{*}{$\frac{\stackrel{\partial}{0}}{\frac{\partial}{0}}$} & Sample code & $\mathrm{Cd}$ & $\mathrm{Cr}$ & $\mathrm{Cu}$ & $\mathrm{Fe}$ & $\mathrm{Mn}$ & $\mathrm{Ni}$ & $\mathrm{Pb}$ & $\mathrm{Zn}$ & $\mathrm{Ca}$ & K & $\mathrm{Mg}$ & $\mathrm{Na}$ \\
\hline & CM10(Un) & ND & 0.05 & 0.8 & 0.7 & 0.6 & ND & 0.6 & 1.6 & 465.7 & 1538.2 & 351.2 & 884.7 \\
\hline & CM15(Un) & ND & 0.02 & 0.3 & 0.4 & ND & ND & 0.7 & 0.7 & 490.9 & 1235.2 & 348.0 & 1094.8 \\
\hline & CM14 (Mx) & ND & 0.05 & 0.3 & 0.5 & 0.5 & ND & 1.4 & 1.0 & 500.4 & 1575.3 & 397.9 & 1298.3 \\
\hline \multirow{4}{*}{ 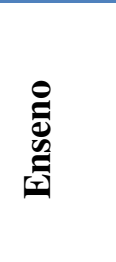 } & CM4 (Mx) & 0.01 & 0.2 & 0.1 & ND & 0.1 & ND & 1.6 & 0.1 & 396.9 & 1114.2 & 301.1 & 823.0 \\
\hline & CM7 (Mx) & ND & 0.1 & 0.5 & ND & 0.5 & ND & 0.2 & 0.6 & 530.2 & 1372.8 & 159.6 & 589.6 \\
\hline & CM2 (Mx) & 0.01 & 0.02 & 0.2 & 0.6 & ND & ND & 0.3 & 0.7 & 401.3 & 1344.6 & 182.5 & 751.5 \\
\hline & CM8(Un) & 0.01 & 0.03 & 0.7 & 0.7 & 0.4 & ND & ND & ND & 521.9 & 1534.8 & 373.5 & 1155.3 \\
\hline \multirow{2}{*}{$\sum^{\frac{\pi}{d}} \frac{e}{d}$} & CM13(Un) & ND & 0.4 & 0.2 & 1.0 & 0.5 & ND & 0.4 & 3.1 & 491.6 & 1591.9 & 223.8 & 855.4 \\
\hline & Blank & ND & ND & ND & ND & ND & ND & ND & ND & ND & ND & ND & ND \\
\hline
\end{tabular}


Note: $\mathbf{U n}=$ Unmixed, $\mathbf{M x}=$ Mixed ND= not detected, $\mathbf{C M}=$ Cow's milk, Blank = Q.s deionized water $+9 \mathrm{~mL} 68 \% \mathrm{HNO}_{3}+2 \mathrm{~mL} 32 \% \mathrm{H}_{2} \mathrm{O}_{2}$.

Table 6: The permissible limit of heavy metals in milk.

\begin{tabular}{|c|c|c|c|c|}
\hline Heavy metals & $\begin{array}{l}\text { Permissible } \\
\text { ppm }\end{array}$ & limit & Heavy metals & Permissible limit ppm \\
\hline Cd & $0.01^{\mathrm{a}}$ & & $\mathrm{Pb}$ & $0.02^{\mathrm{a}}$ \\
\hline $\mathrm{Cr}$ & $0.3^{\mathrm{a}}$ & & $\mathrm{Zn}$ & $2.5-6.7^{b}$ \\
\hline $\mathrm{Cu}$ & $0.4^{\mathrm{d}}$ & & $\mathrm{Ca}$ & $820-1130^{b}$ \\
\hline $\mathrm{Fe}$ & $1-6^{b}$ & & $\mathrm{Mg}$ & $80-120^{b}$ \\
\hline Mn & $0.2^{c}$ & & $\mathrm{~K}$ & $1320-3480^{b}$ \\
\hline $\mathbf{N i}$ & $0.2^{\mathrm{a}}$ & & $\mathrm{Na}$ & $248-2921^{b}$ \\
\hline
\end{tabular}

Where;

$\mathrm{a}=$ Codex Alimentarius Commission (2012)

$b=$ From the composition of Chinese foods

$\mathrm{c}=$ From Standard tables of food composition in Japan (2015)

d=Egyptian standard (2001)

Table7: Comparison of daily intakes of metals with Recommended Daily Allowance (RDA) values.

\begin{tabular}{|llll|} 
Element in milk & $\begin{array}{l}\text { Concentration } \\
(\mathbf{m g} / \mathrm{L})\end{array}$ & $\begin{array}{l}\text { Estimated Daily intake } \\
(\mathbf{m g} / \text { day }) \text { in this study }\end{array}$ & $\begin{array}{l}\text { Recommended Daily } \\
\text { Allowance (mg/day) }\end{array}$ \\
\hline $\mathbf{C d}$ & 0.0053 & 0.002809 & $0.057-0.072$ \\
\hline $\mathbf{C r}$ & 0.724 & 0.0384 & $0.05-0.2$ \\
\hline $\mathbf{C u}$ & 0.4547 & 0.0241 & $2-3$ \\
\hline $\mathbf{F e}$ & 0.55 & 0.0291 & $0.27-27$ \\
\hline $\mathbf{M n}$ & 0.3547 & 0.019 & $2-5$ \\
\hline $\mathbf{P b}$ & 2 & 0.106 & 0.429 \\
\hline $\mathbf{Z n}$ & 1.288 & 0.0683 & $12-15$ \\
\hline
\end{tabular}




\begin{tabular}{|llll|}
\hline Ca & 478.511 & 25.361 & $200-1300$ \\
\hline K & 1458.888 & 77.3211 & $400-5100$ \\
\hline $\mathbf{M g}$ & 245.5235 & 13.013 & $30-320$ \\
\hline Na & 817.2412 & 43.314 & $120-1500$ \\
\hline
\end{tabular}

\section{List of Figures:}

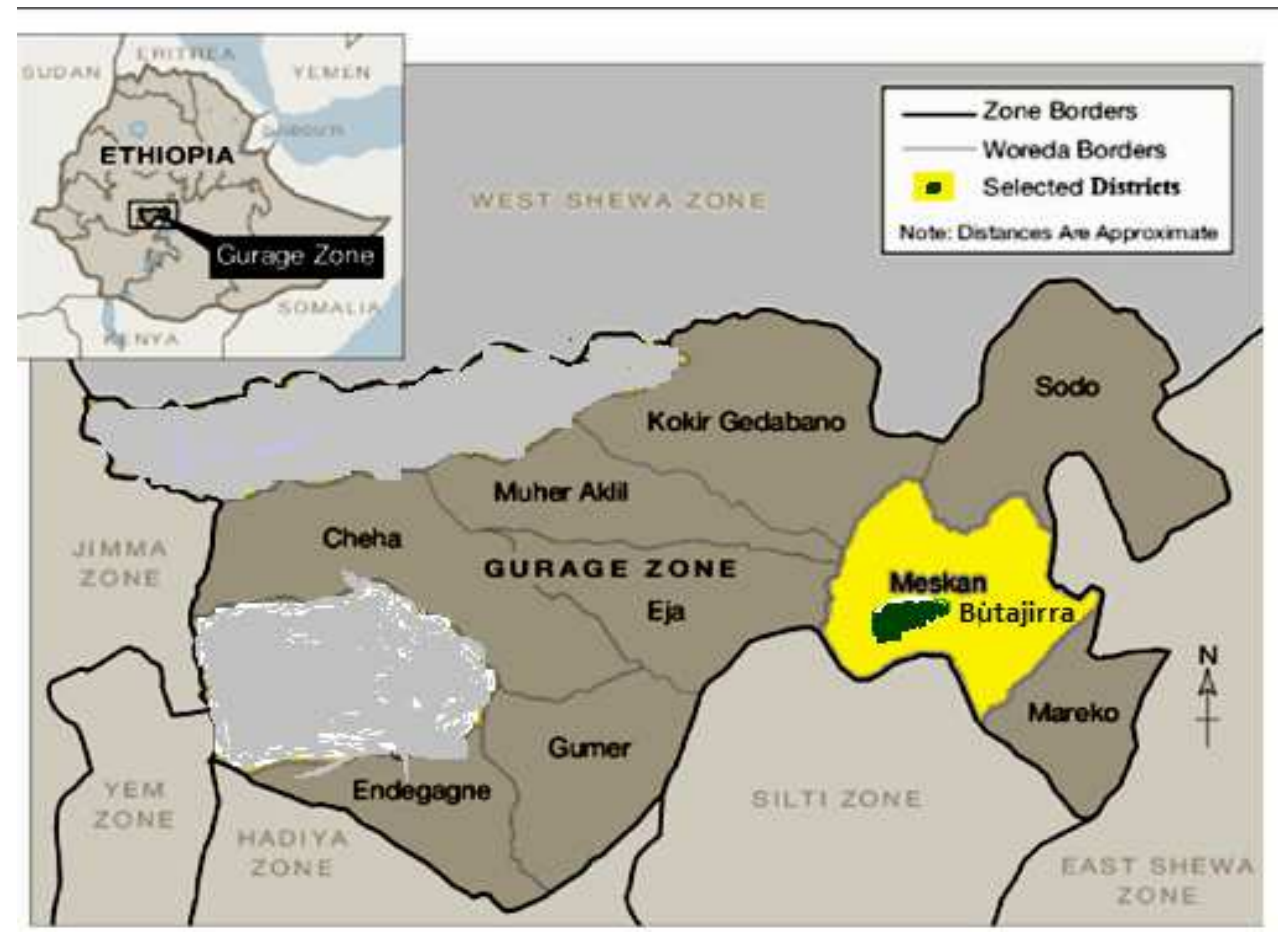

Figure 1: Map of Gurage zone of Ethiopia displaying districts selected for the study 


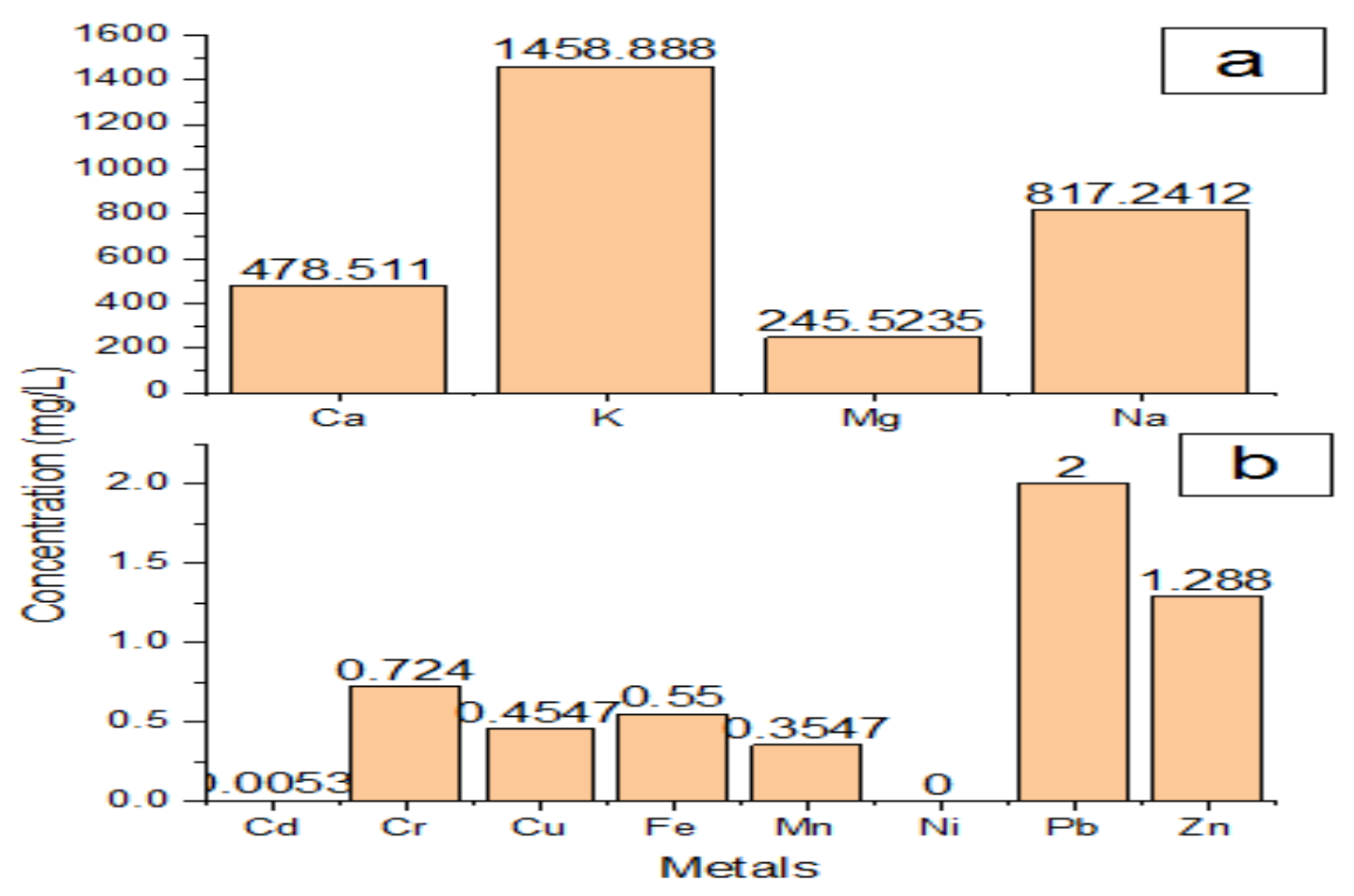

Figure 2: The average values for each metal in all samples (in $\mathrm{mg} / \mathrm{L}$ ) 


\section{Figures}

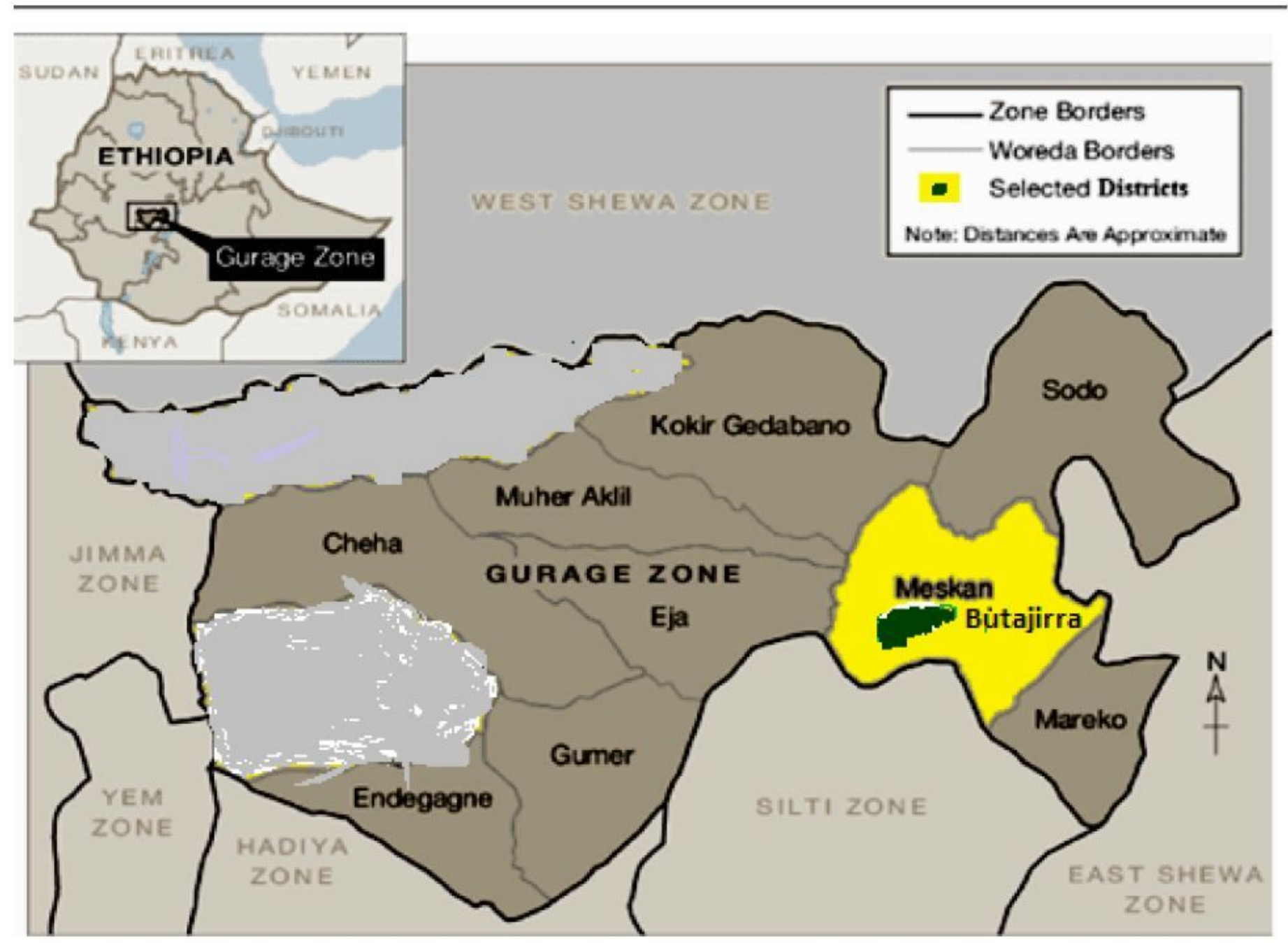

\section{Figure 1}

Map of Gurage zone of Ethiopia displaying districts selected for the study. Note: The designations employed and the presentation of the material on this map do not imply the expression of any opinion whatsoever on the part of Research Square concerning the legal status of any country, territory, city or area or of its authorities, or concerning the delimitation of its frontiers or boundaries. This map has been provided by the authors. 


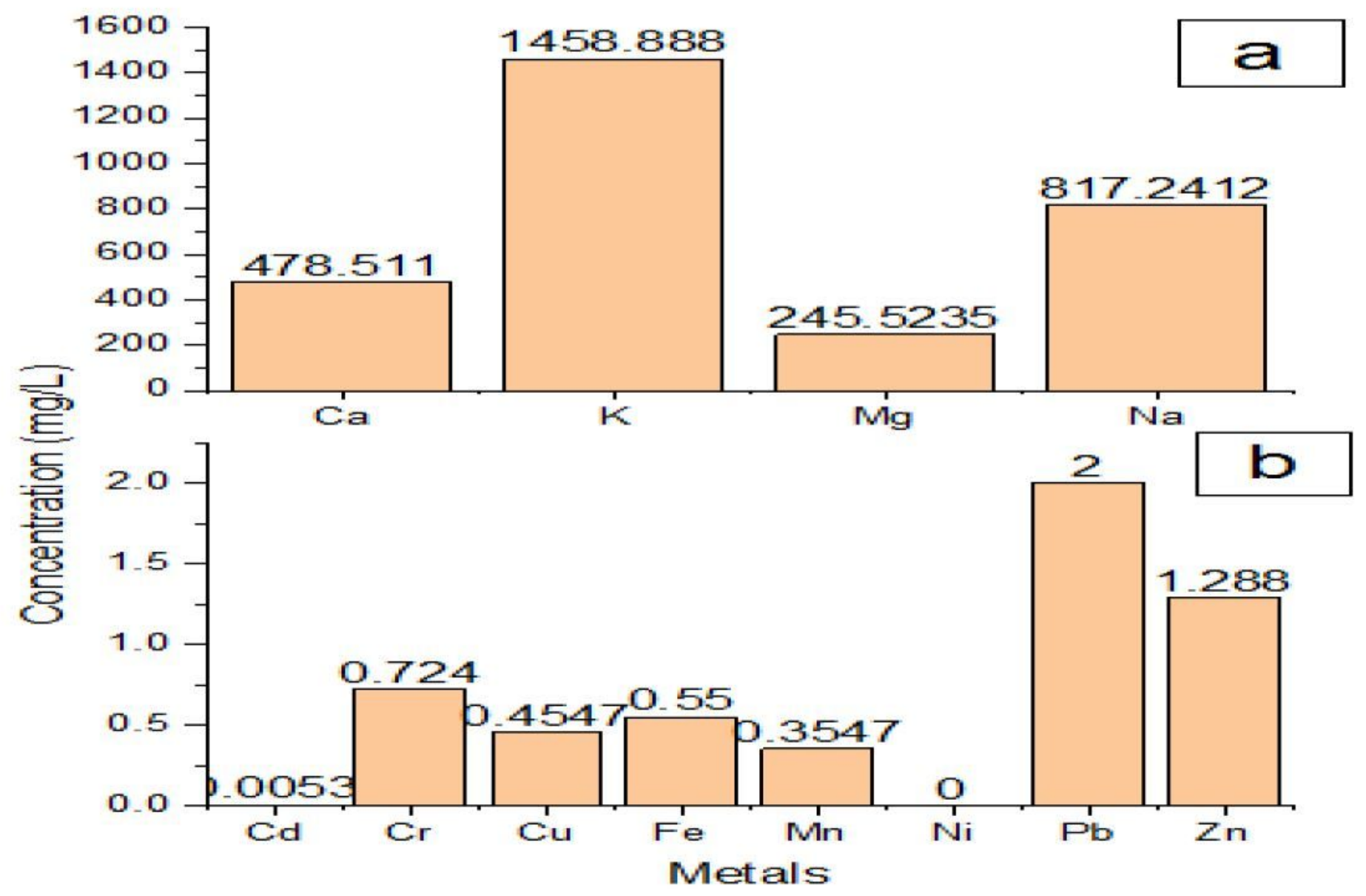

Figure 2

The average values for each metal in all samples (in $\mathrm{mg} / \mathrm{L}$ ) 